\title{
The Contribution of Reservoirs to Global Land Surface Water Storage Variations*
}

\author{
TIAN $\mathrm{ZHOU}^{+}$AND BART NIJSSEN \\ Department of Civil and Environmental Engineering, University of Washington, Seattle, Washington \\ HUILIN GAO \\ Zachry Department of Civil Engineering, Texas A\&M University, College Station, Texas \\ DENNIS P. LETTENMAIER ${ }^{\#}$ \\ Department of Civil and Environmental Engineering, University of Washington, Seattle, Washington
}

(Manuscript received 8 January 2015, in final form 2 September 2015)

\begin{abstract}
Man-made reservoirs play a key role in the terrestrial water system. They alter water fluxes at the land surface and impact surface water storage through water management regulations for diverse purposes such as irrigation, municipal water supply, hydropower generation, and flood control. Although most developed countries have established sophisticated observing systems for many variables in the land surface water cycle, long-term and consistent records of reservoir storage are much more limited and not always shared. Furthermore, most land surface hydrological models do not represent the effects of water management activities. Here, the contribution of reservoirs to seasonal water storage variations is investigated using a large-scale water management model to simulate the effects of reservoir management at basin and continental scales. The model was run from 1948 to 2010 at a spatial resolution of $0.25^{\circ}$ latitude-longitude. A total of 166 of the largest reservoirs in the world with a total capacity of about $3900 \mathrm{~km}^{3}$ (nearly $60 \%$ of the globally integrated reservoir capacity) were simulated. The global reservoir storage time series reflects the massive expansion of global reservoir capacity; over 30000 reservoirs have been constructed during the past half century, with a mean absolute interannual storage variation of $89 \mathrm{~km}^{3}$. The results indicate that the average reservoir-induced seasonal storage variation is nearly $700 \mathrm{~km}^{3}$ or about $10 \%$ of the global reservoir storage. For some river basins, such as the Yellow River, seasonal reservoir storage variations can be as large as $72 \%$ of combined snow water equivalent and soil moisture storage.
\end{abstract}

\section{Introduction}

Freshwater is a key limiting resource for human development. Nearly $70 \%$ of global freshwater is stored with relatively long retention periods in ice caps, glaciers, permanent snow, and groundwater (USGS 2014).

\footnotetext{
* Supplemental information related to this paper is available at the Journals Online website: http://dx.doi.org/10.1175/JHM-D-150002.s1.

${ }^{+}$Current affiliation: Pacific Northwest National Laboratory, Richland, Washington.

\# Current affiliation: Department of Geography, University of California, Los Angeles, Los Angeles, California.
}

Corresponding author address: Dr. Dennis P. Lettenmaier, Department of Geography, University of California, Los Angeles, Los Angeles, CA 90095.

E-mail: dlettenm@ucla.edu
Freshwater stored with much shorter retention times in rivers, lakes, seasonal snow, and soil moisture is the main contributor to storage variability in large-scale water budgets at seasonal and interannual scales (Kinter and Shukla 1990) and is the source of most of the water used by humans.

Water management activities, such as irrigation and municipal water supply, hydropower generation, and flood control, substantially alter freshwater fluxes at the land surface and impact surface water storage through redistribution in space and time. Since the early 1900s, the global irrigated agricultural area has increased sixfold to approximately $3.2 \times 10^{6} \mathrm{~km}^{2}$ or about $2 \%$ of the global land area according to FAO Global Map of Irrigation Areas (GMIA) dataset (Siebert et al. 2013). Total irrigation water withdrawals are now about $2700 \mathrm{~km}^{3}$ $\mathrm{yr}^{-1}$ and account for about $70 \%$ of the consumptive water use globally (Gordon et al. 2005). To accommodate this rapid increase in irrigation water demand, more 
than 30000 large dams have been built globally during the past half century, which impound almost $7000 \mathrm{~km}^{3}$ water (Vörösmarty et al. 2003; Hanasaki et al. 2006) or nearly $20 \%$ of annual river runoff (Vörösmarty et al. 1997; White 2005). Biemans et al. (2011) estimated that irrigation and reservoir regulation have decreased global discharge by $2.1 \%$ or $930 \mathrm{~km}^{3} \mathrm{yr}^{-1}$. In arid or semiarid river basins, the impact of irrigation and reservoir operation may be amplified. Wang et al. (2006) analyzed the runoff from the Yellow River and suggested that anthropogenic activities have shifted streamflow patterns and are responsible for a decrease in the discharge of the river by nearly one-half over the past 50 years.

Water retained by global reservoirs has also created a "drag" on global sea level rise. Chao et al. (2008) estimated that man-made reservoirs have caused an equivalent sea level drop of about $30 \mathrm{~mm}\left(-0.55 \mathrm{~mm} \mathrm{yr}^{-1}\right)$ over the past 50 years. Lettenmaier and Milly (2009) gave a slightly smaller estimate of $-0.5 \mathrm{~mm} \mathrm{yr}^{-1}$ at the decadal time scale and suggested that the rate has slowed in recent years because of a slowdown in new dam construction.

In addition to their long-term impacts on the global and regional water cycles, artificial impoundments also reshape variations in water storage and streamflow at seasonal and interannual time scales. Hanasaki et al. (2006) simulated 2-yr operations of 452 global reservoirs and found that the maximum change in monthly runoff as a result of reservoir operation was as large as $34 \%$ in 18 basins around the globe. Haddeland et al. (2006) modeled anthropogenic impacts on seasonal surface water fluxes for a set of global river basins and suggested that monthly streamflow in the western United States decreased by as much as $30 \%$ in June because of irrigation and reservoir regulations, while monthly streamflow increased by as much as 30\% in Arctic river basins in Asia during the winter low-flow period. Oki and Kanae (2006) argue that these variations in streamflow can lead to water-related hazards such as droughts and floods if societies fail to anticipate or monitor these changes in the hydrological cycle. Furthermore, variations in reservoir storage have important implications for the carbon cycle. For example, Tranvik et al. (2009) estimated that the $\mathrm{CO}_{2}$ emissions to the atmosphere from global inland waters (including lakes, reservoirs, wetlands, and rivers) are similar in magnitude to the $\mathrm{CO}_{2}$ uptake by the global oceans.

Several studies have attempted to quantify the seasonal and interannual variability of water budget components on the global scale (Dirmeyer 1995; Coughlan and Avissar 1996; Biancamaria et al. 2010; Nijssen et al. 2001b; Gao et al. 2012; Pokhrel et al. 2012). However, long-term and consistent records that focus on water management and human impacts on the global water cycle are not widely available. Gauge networks that record reservoir storage are less unified than stream gauge networks and their records are not always shared. Large-scale modeling tools that integrate hydrology and anthropogenic impacts have mostly been used at annual time scales (e.g., Chao et al. 2008; Döll et al. 2009) and studies that investigate the contribution of human activities to seasonal variations of global surface water storage are still lacking. Here we describe a large-scale water management model that estimates the effects of irrigation and reservoir storage on global and continental water cycles by integrating the macroscale hydrological Variable Infiltration Capacity model (VIC; Liang et al. 1994), a soil-moisture-deficit-based irrigation scheme, and a basin-scale reservoir storage module. The specific questions we address are as follows:

1) What is the magnitude of seasonal variations in reservoir storage at continental and global scales?

2) How large are seasonal reservoir storage variations compared with the seasonal variations in other land surface water storage terms such as soil moisture and seasonal snow?

3) What is the magnitude of interannual global reservoir storage variations over the period 1948-2010, during which many dams were built?

\section{Methods and data}

We simulated irrigation water use and reservoir operations in 32 global river basins (Fig. 1) with a largescale water management model to quantify the monthly variations of reservoir storage within selected large river basins. Within these 32 basins we explicitly simulated 166 large reservoirs with a total capacity of $3900 \mathrm{~km}^{3}$, which accounts for nearly $60 \%$ of the global reservoir capacity.

\section{a. Water management model}

The water management model we used was developed by Haddeland et al. (2006) and has two components: 1) a modified version of the VIC (VIC-IRR), which includes a soil-moisture-deficit-based irrigation scheme (IRR), and 2) a reservoir module for dam release optimizations.

VIC-IRR integrates a standardized method of irrigation scheduling into the regular VIC (VIC, version 4.0.6). Within each grid cell, the irrigated area is represented as a fraction of the cell area, in the same manner that other land-cover types are represented (see Liang et al. 1994). The automatic irrigation scheduling is based on the VIC-predicted soil moisture content for agricultural grid cells at every computational step. Specifically, 


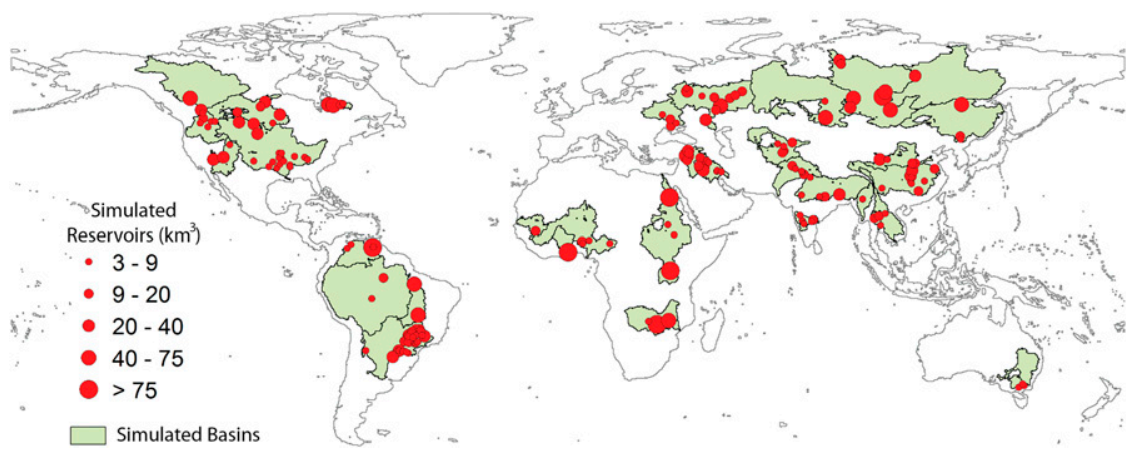

FIG. 1. Model-simulated basins and reservoirs.

irrigation is represented in the model as additional precipitation during the growing season that occurs when the soil moisture drops below the wilting point. Water added to the irrigated grid cells is taken from local gridcell runoff and upstream reservoirs. The additional precipitation continues on a daily basis until soil moisture reaches field capacity or until reservoir storage is exhausted.

The reservoir module is coupled with a simple routing model (Lohmann et al. 1996, 1998) to simulate dam releases for single or multiple purposes such as irrigation, flood control, hydropower, and water supply. The Shuffled Complex Evolution Metropolis algorithm of the University of Arizona (SCEM-UA; Vrugt et al. 2003 ) is used to optimize monthly dam releases $Q_{\text {out }}$ given the reservoir inflow $Q_{\text {in }}$, storage $S$, installed capacity (represented by hydrostatic head $h$ ), downstream irrigation water demand $Q_{d}$, flood (maximum) discharge $Q_{f}$, and minimum dam release $Q_{\text {min }}$. The objective functions (listed in Table 1) for the optimization were determined by the main uses of each dam as specified in the Global Reservoir and Dam (GRanD) database (Lehner et al. 2011). The optimization procedure was executed in series when a dam had multiple purposes. Irrigation demands were given priority, followed by flood control. Where applicable, any excess water was used to maximize hydropower production. Readers are referred to Haddeland et al. (2006) for more details of the water management model.

Simulation of the optimized dam releases required three simulations with VIC-IRR. The first VIC-IRR simulation was a standard VIC run without irrigation water extraction to determine evapotranspiration in the absence of irrigation $\left(\mathrm{EVAP}_{\mathrm{reg}}\right)$ as well as $Q_{f}$ and $Q_{\min }$. The latter two were determined after routing the flow to each reservoir grid cell and calculating the mean of the annual maximum daily discharges (i.e., $Q_{f}$ ) and the 7-day consecutive low flow with a 10 -yr recurrence period (i.e., $Q_{\min }$ ). The second VIC-IRR simulation was used to determine evapotranspiration under the assumption that water is freely available $\left(\mathrm{EVAP}_{\text {free }}\right)$ at all times. For each irrigated grid cell, the monthly irrigation water demand was estimated as $\mathrm{EVAP}_{\text {free }}$

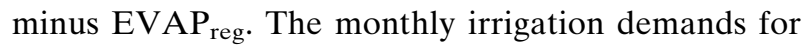
each reservoir (i.e., $Q_{d}$ ) were then estimated by summing the demands from the downstream grid cells with a maximum distance of ten $0.25^{\circ}$ grid cells $(\sim 250 \mathrm{~km})$ from the river stem. If multiple reservoirs were located in separate tributaries upstream of an irrigated area, demands from the downstream grid cells were divided among the reservoirs based on the reservoir capacities. For reservoirs located on the same river, irrigation demand for each reservoir was derived from the entire downstream areas (including the shared area). During the third (and also the final) model run, reservoirs located within the same river basin were simulated in sequence from upstream to downstream. Aside from differences associated with travel time in the channel system, $Q_{\text {in }}$ to the downstream reservoir is essentially the sum of $Q_{\text {out }}$ from the upstream reservoir and the streamflow from the contributing area between the two reservoirs. The model was run for the 63-yr period from 1948 through 2010 at a daily time step at $0.25^{\circ}$ latitude-longitude resolution for the basins in Fig. 1. A 43-yr model simulation (1948-90) was used to produce the initial soil moisture and snow state for the model runs over the entire period. Reservoir storage was set to $80 \%$ of the capacity as the initial state. The vegetation and crop parameters were fixed over the modeling period. Monthly reservoir storage time series were extracted starting from 1948 or from the year the dam was built through 2010. Other water budget terms, including the soil moisture in all three soil layers, surface runoff, base flow, and snow water equivalent (SWE), were exported and converted to mean monthly values (in the case of fluxes such as surface runoff and base flow) or end of month values (in the case of states such as soil moisture storage or SWE). 
TABLE 1. Objective functions for reservoir purposes [taken from Haddeland et al. (2006), where $Q_{d}$ is irrigation water demands; $Q_{r}$ is reservoir release; $Q_{\text {flood }}$ is mean annual flood, based on simulated naturalized flow; $Q_{\text {mean }}$ is mean annual flow; $\rho$ is density of water; $\eta$ is efficiency of the power generating system; $h$ is hydrostatic pressure head; and $g$ is acceleration of gravity].

\begin{tabular}{lcl}
\hline \hline \multicolumn{1}{c}{ Purpose } & \multicolumn{1}{c}{ Objective function } & Notes \\
\hline Irrigation & $\min \sum_{i=1}^{365}\left(Q_{d_{i}}-Q_{r_{i}}\right), Q_{d}>Q_{r}$ & Minimize the irrigation deficits \\
Flood control & $\min \sum_{i=1}^{365}\left(Q_{r_{i}}-Q_{\text {flood }}\right)^{2}, Q_{r}>Q_{\text {flood }}$ & Minimize the differences between dam release and $Q_{\text {flood }}$ \\
Hydropower & $\min \sum_{i=1}^{365} \frac{1}{Q_{r_{i}} \rho \eta h g}$ & Maximize the hydropower generation \\
Water supply & $\min \sum_{i=1}^{365}\left|Q_{r_{i}}-Q_{\text {mean }}\right|$ & Minimize the dam release and the mean annual flow \\
\hline
\end{tabular}

\section{b. Study basins}

We focused on 32 river basins that we selected based on two criteria: 1) the river basin should contain at least one reservoir with a capacity greater than $3 \mathrm{~km}^{3}$ and 2) the area of the river basin should be larger than $600000 \mathrm{~km}^{2}$. The storage threshold was selected because the 300 largest reservoirs (capacity $>3 \mathrm{~km}^{3}$ ) account for over $75 \%$ of the total global reservoir storage capacity (Lehner et al. 2011). The area threshold was selected because basins with an area greater than $600000 \mathrm{~km}^{2}$ account for almost half of the global land area excluding Greenland and Antarctica according to the UNH/GRDC Runoff Fields dataset (Fekete et al. 2002). Combining these two selection criteria resulted in 25 basins. Seven additional basins were selected (La Grande, Tocantins, Senegal, Volta, Chao Phraya, Dnieper, and Krishna) because they have relatively large reservoirs with small basin areas. For example, the La Grande basin in North America has four reservoirs with a capacity greater than $3 \mathrm{~km}^{3}$ (for a total capacity of $160 \mathrm{~km}^{3}$ ), but the drainage area is only $100000 \mathrm{~km}^{2}$. We included these basins in the interest of representing as much of the total global reservoir capacity as possible. Basins such as the Congo, which have a large drainage area but little reservoir storage, were excluded. The final 32 basins include 166 reservoirs (Fig. 1), which account for $87 \%$ of the total reservoir capacity within those basins, and nearly $60 \%$ of the total global reservoir capacity. The total storage within the 166 reservoirs is about $3900 \mathrm{~km}^{3}$.

\section{c. Model inputs and calibration}

\section{1) Model inPuts}

The inputs to the hydrology component of the integrated water management model include meteorological forcing data, soil and vegetation parameters, and routing information. Crop and reservoir information are required for the irrigation scheme and reservoir module, respectively.

An extended version of the Sheffield et al. (2006) global dataset of near-surface meteorological variables was used for meteorological forcings for the period from 1 January 1948 to 31 December 2010. Spatially distributed soil and vegetation characteristics were specified following Nijssen et al. (2001a). For the irrigated grid cells, the percentage of irrigated area and the crop calendar used to specify irrigation demand were obtained from the International Water Management Institute (IWMI) database Global Irrigated Area Mapping (GIAM; Thenkabail et al. 2009). Crop coefficients and heights specified by FAO were used to calculate the monthly leaf area index (LAI) values throughout the growing season and were integrated into the vegetation characteristics. Global river networks at $0.25^{\circ}$ spatial resolution were taken from Wu et al. (2011) with slight flow path modifications at northern Mekong basin. Reservoir characteristics, including the latitude and longitude of the controlling dams, reservoir capacity, surface area, built year, and operating purposes, were taken from the GRanD database (Lehner et al. 2011).

\section{2) Hydrology MODEL CALIBRATION}

We calibrated the soil parameters for VIC-IRR to ensure realistic reservoir inflow observations to the extent possible. For each river basin, a naturalized (i.e., undammed) monthly gauge observation near the basin outlet was selected from various databases including the Global Runoff Data Centre (GRDC) database (http:// www.bafg.de/GRDC/EN/Home/homepage_node.html), U.S. Geological Survey (USGS) Water Data (http:// waterdata.usgs.gov/nwis), Large-Scale Biosphere Atmosphere Experiment in Amazonia (LBA) data (http://eosearthdata.sr.unh.edu/data/data9.jsp), R-ArcticNET data (http://www.r-arcticnet.sr.unh.edu/v4.0/index.html), and U.S. Bureau of Reclamation (USBR) Colorado River basin natural flow data (http://www.usbr.gov/lc/region/g4000/ NaturalFlow/) based on availability. For most locations that have gauged flows (rather than naturalized flows), we used the period that precedes the earliest dam construction within the basin (see Table S1 in the supplemental material). 

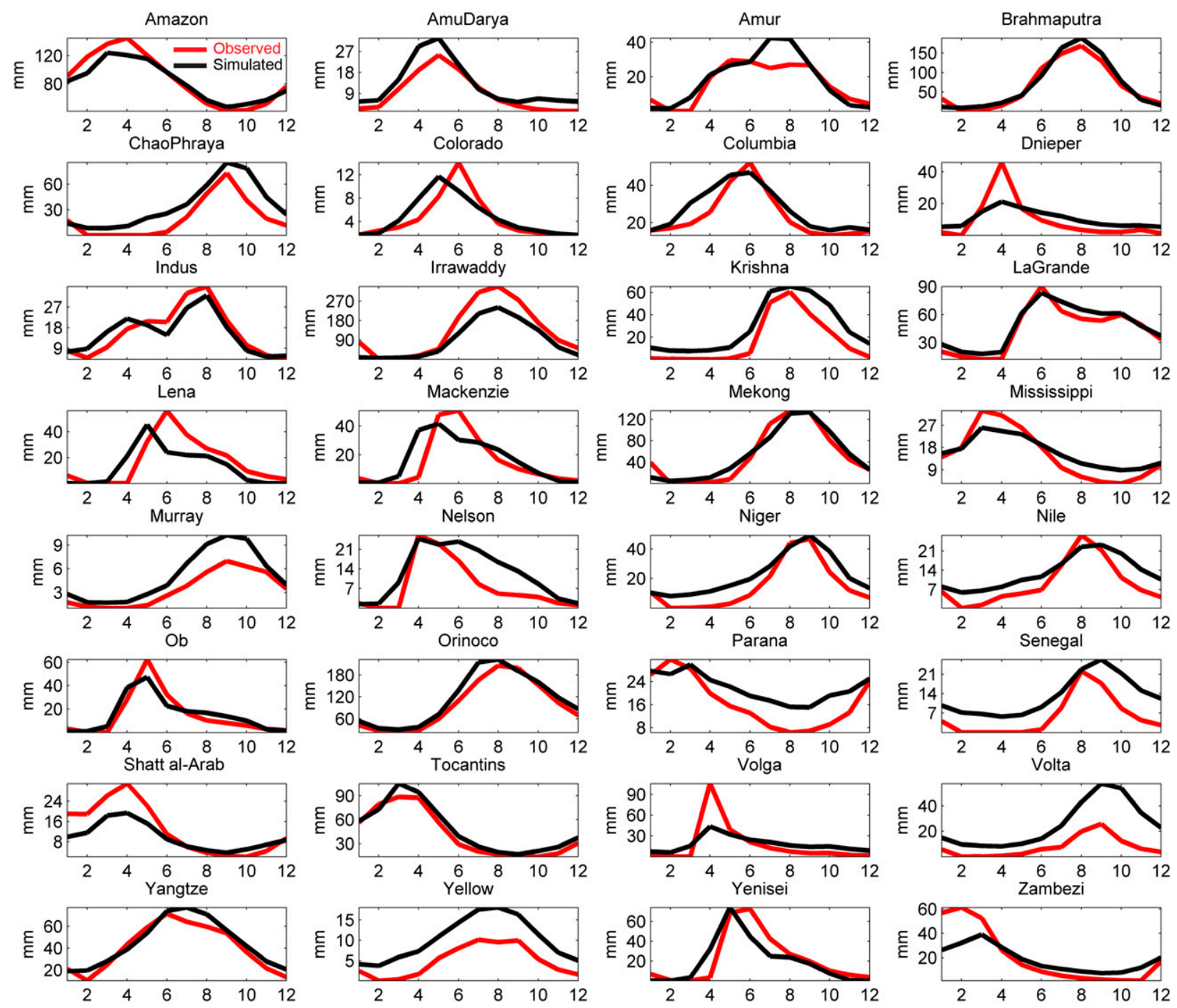

FIG. 2. Calibrated seasonal runoff compared with naturalized/undammed streamflow at gauge location for 32 simulated basins.

Rather than calibrating the routed streamflow against naturalized flow at the gauge station, we first disaggregated the streamflow to produce spatially distributed runoff fields within each basin using the scaling method of J. Sheffield et al. (2015, unpublished manuscript) and then calibrated the model parameters for each model grid cell independently. The disaggregation method assumes that a baseline VIC run (using uniform parameter values for all grid cells) provides a reasonable spatial distribution of the runoff. In that case, runoff for each grid cell can be estimated as a function of the baseline VIC runoff for that grid cell, the ratio between the measured (or naturalized) and VIC-simulated flow at the gauge station, and the (estimated) travel time from this grid cell to the gauge station [see J. Sheffield et al. (2015, unpublished manuscript) for details]. For each basin, the naturalized (undammed) monthly streamflow time series at the gauge location was disaggregated into a mean, monthly cycle at each grid cell with a spatial resolution of $1^{\circ}$ (i.e., 12 values per grid cell). Given that the record of the naturalized (undammed) streamflow is relatively short (median about 20 years, with fewer than 10 years for seven basins), we did not perform a split-sample calibration (separate calibration and validation period) in the interest of retaining as much information as possible for calibration.

We used the Shuffled Complex Evolution algorithm of the University of Arizona (SCE-UA) from Duan et al. (1994) to minimize the mean absolute error (MAE) of the mean monthly values between the modelsimulated and the disaggregated runoff at each grid cell over the period of the naturalized or undammed flow record. We chose MAE as the objective function because 
TABLE 2. The 23 simulated reservoirs with satellite estimates (Gao et al. 2012), ranked by capacity.

\begin{tabular}{|c|c|c|c|c|}
\hline Reservoir & Capacity $\left(\mathrm{km}^{3}\right)$ & Dam & Dam location (lat, lon) & Basin \\
\hline Nasser & 162 & High Aswan & $23.97^{\circ} \mathrm{N}, 32.88^{\circ} \mathrm{E}$ & Nile \\
\hline Guri & 135 & Guri & $7.76^{\circ} \mathrm{N}, 63^{\circ} \mathrm{W}$ & Orinoco \\
\hline Williston & 74 & W. A. C. Bennett & $56.01^{\circ} \mathrm{N}, 122.2^{\circ} \mathrm{W}$ & Mackenzie \\
\hline Krasnoyarsk & 73 & Krasnoyarsk & $55.5^{\circ} \mathrm{N}, 92^{\circ} \mathrm{E}$ & Yenisei \\
\hline Tucurui & 50 & Tucurui & $3.88^{\circ} \mathrm{S}, 49.74^{\circ} \mathrm{W}$ & Tocantins \\
\hline Tharthar & 44 & Tharthar & $33.79^{\circ} \mathrm{N}, 43.58^{\circ} \mathrm{E}$ & Shatt al-Arab \\
\hline Mead & 37 & Hoover & $36.01^{\circ} \mathrm{N}, 114.74^{\circ} \mathrm{W}$ & Colorado \\
\hline Sakakawea & 30 & Garrison & $47.5^{\circ} \mathrm{N}, 101.42^{\circ} \mathrm{W}$ & Mississippi \\
\hline Oahe & 29 & Oahe & $44.45^{\circ} \mathrm{N}, 100.39^{\circ} \mathrm{W}$ & Mississippi \\
\hline Rybinsk & 25 & Rybinsk & $58.08^{\circ} \mathrm{N}, 38.75^{\circ} \mathrm{E}$ & Volga \\
\hline Ilha Solteira & 25 & Ilha Solteira & $20^{\circ} \mathrm{S}, 51^{\circ} \mathrm{W}$ & Parana \\
\hline Powell & 25 & Glen Canyon & $36.94^{\circ} \mathrm{N}, 114.48^{\circ} \mathrm{W}$ & Colorado \\
\hline Fort Peck & 24 & Fort Peck & $48^{\circ} \mathrm{N}, 106.42^{\circ} \mathrm{W}$ & Mississippi \\
\hline Toktogul & 20 & Toktogul & $41.78^{\circ} \mathrm{N}, 72.83^{\circ} \mathrm{E}$ & Amu Darya \\
\hline Kainji & 15 & Kainji & $10.4^{\circ} \mathrm{N}, 4.55^{\circ} \mathrm{E}$ & Niger \\
\hline Kremenchuk & 14 & Kremenchuk & $49.08^{\circ} \mathrm{N}, 33.25^{\circ} \mathrm{E}$ & Dnieper \\
\hline Nova Ponte & 13 & Nova Ponte & $19.15^{\circ} \mathrm{S}, 47.33^{\circ} \mathrm{W}$ & Parana \\
\hline Mosul & 13 & Mosul & $36.63^{\circ} \mathrm{N}, 42.82^{\circ} \mathrm{E}$ & Shatt al-Arab \\
\hline Qadisiyah & 11 & Haditha & $34.21^{\circ} \mathrm{N}, 42.36^{\circ} \mathrm{E}$ & Shatt al-Arab \\
\hline Karakaya & 10 & Karakaya & $38.5^{\circ} \mathrm{N}, 38.5^{\circ} \mathrm{E}$ & Shatt al-Arab \\
\hline Novosibirskoye & 9 & Novosibirskoye & $54.5^{\circ} \mathrm{N}, 82^{\circ} \mathrm{E}$ & $\mathrm{Ob}$ \\
\hline Chardara & 7 & Chardara & $41^{\circ} \mathrm{N}, 68^{\circ} \mathrm{E}$ & Amu Darya \\
\hline Roseires & 3 & Roseires & $11.6^{\circ} \mathrm{N}, 34.38^{\circ} \mathrm{E}$ & Nile \\
\hline
\end{tabular}

it captures the monthly streamflow peak in a year, while reducing overall errors. The calibrated parameters are 1) the infiltration curve parameter $b$, which specifies the shape of the curve that parameterizes the subgrid partitioning of precipitation into fast response runoff and infiltration; 2) parameters that define the nonlinear baseflow recession (drainage from the lower layer), including maximum baseflow velocity (Dsmax), the fraction of Dsmax where nonlinear baseflow begins (Ds), and the fraction of maximum soil moisture where nonlinear baseflow occurs (Ws); 3) exp, a parameter that characterizes the variation of saturated hydraulic conductivity with soil moisture; and 4) the thickness of the second and third soil layers, which allow for soil moisture storage and supply base flow. It should be noted that the hydrology part of the model was calibrated without taking into account irrigation and reservoir operations-we believe that this is justified as the irrigated areas in general are small compared with total drainage areas, and the streamflow observations we used are either corrected for reservoir effects or taken before the major reservoirs were built. The calibrated soil parameters at a $1^{\circ}$ spatial resolution were then mapped to the $0.25^{\circ}$ spatial resolution by replacing all sixteen $0.25^{\circ}$ gridcell values with the $1^{\circ}$ calibrated values.

The calibrated seasonal streamflow values were then compared with the gauge observations we used during the calibration for all 32 basins (Fig. 2). The comparisons showed a good match in most basins with over $70 \%$ basins having a mean absolute percentage error (MAPE) of less than $20 \%$ for the predicted seasonal cycle, suggesting that the model was able to produce plausible hydrology outputs for the selected basins during the simulation period and in turn for the inflow to the simulated reservoirs.

\section{Results}

\section{a. Comparison with satellite estimates}

We compared our simulated reservoir storage with satellite-based estimates from Gao et al. (2012), who estimated monthly storage for 34 large reservoirs based on combinations of water surface elevation from satellite altimetry and water surface area from satellite image classifications for the period 1992-2010. Twenty-three of the reservoirs included in Gao et al. (2012) also lie within 14 of our river basins (Table 2) and hence were simulated. We computed the mean seasonal cycles of the reservoir storage for our model simulations over the same period for which satellite estimates were available and validated the results for each reservoir (Fig. 3).

In many cases, the simulated seasonal cycle was generally in agreement with the satellite estimates in both magnitude and variability. However, for some reservoirs (Sakakawea and Oahe), the $25 \%-75 \%$ percentile band (which indicates how large the interannual storage variation could be during the simulation period) of the satellite estimates was wider than for the simulations, suggesting that the model-simulated storage had relatively smaller interannual variations than the satellite 

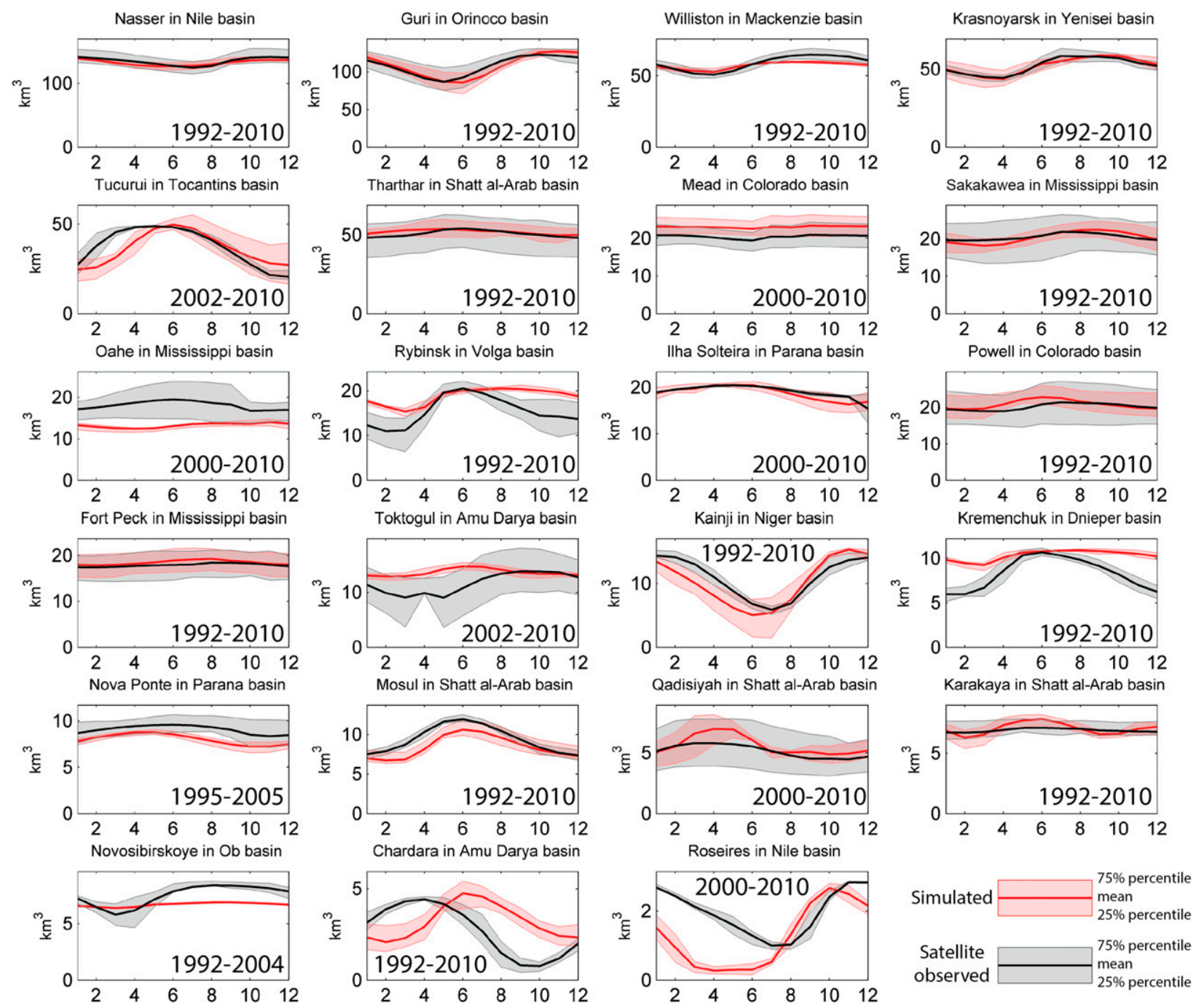

FIG. 3. Simulated seasonal reservoir storage compared with satellite estimates derived by Gao et al. (2012). Comparison period is provided.

observations. There are several possible reasons for these differences. One is the model assumption of no changes in crop coverage, irrigation schedules, and dam purposes over the simulation period. In addition, actual reservoir operations often diverge from stated operations rules [see Christensen et al. (2004) for an example in the Colorado River basin]. Furthermore, in our case, we inferred the operating purposes, and hence rules, rather than taking them from operations guidelines (which are not available in most cases).

For a few reservoirs (most of them are relatively small with capacity less than $10 \mathrm{~km}^{3}$ ), there are mismatches in the timing of the seasonal cycle (Toktogul, Roseires, and Chardara) and the magnitude of storage variations (Kremenchuk, Novosibirskoye, and Karakaya). Possible reasons are that 1) the assumed operating policy may diverge from the actual, 2) irrigation demands serviced by the reservoir may not have been estimated accurately because of the simplified assumptions about irrigation withdrawal and fixed crop fractions, 3) uncertainties and errors are introduced by the model and climate forcing data, and 4) there are uncertainties in the satellite estimates of storage variations. These factors arguably apply to all the simulated reservoirs, but the relatively small reservoirs tend to show larger errors.

\section{b. Storage term variations at basin scale}

Based on the simulated storage changes for the 166 simulated reservoirs, we estimated the total reservoir storage variation for each basin by scaling the simulated reservoir storage values within that same basin. That is, 
TABLE 3. Summary of the simulated and projected reservoirs in 32 basins.

\begin{tabular}{|c|c|c|c|c|c|c|}
\hline Continent & Basin & $\begin{array}{l}\text { No. of simulated } \\
\text { reservoirs }\end{array}$ & $\begin{array}{c}\text { Capacity } \\
\text { simulated }\left(\mathrm{km}^{3}\right)\end{array}$ & $\begin{array}{l}\text { Total reservoir } \\
\text { number in basin }\end{array}$ & $\begin{array}{c}\text { Basin total } \\
\text { capacity }\left(\mathrm{km}^{3}\right)\end{array}$ & $\begin{array}{l}\text { Projection } \\
\text { factor }\end{array}$ \\
\hline \multirow[t]{6}{*}{ North America } & Colorado & 3 & 75 & 81 & 91 & 1.22 \\
\hline & Columbia & 7 & 72 & 127 & 109 & 1.52 \\
\hline & La Grande & 4 & 164 & 5 & 166 & 1.01 \\
\hline & Mackenzie & 1 & 84 & 13 & 86 & 1.02 \\
\hline & Mississippi & 18 & 179 & 723 & 376 & 2.08 \\
\hline & Nelson & 5 & 93 & 89 & 118 & 1.27 \\
\hline \multirow[t]{4}{*}{ South America } & Amazon & 2 & 23 & 8 & 25 & 1.08 \\
\hline & Orinoco & 4 & 167 & 17 & 177 & 1.06 \\
\hline & Parana & 26 & 322 & 72 & 357 & 1.11 \\
\hline & Tocantins & 2 & 118 & 4 & 120 & 1.02 \\
\hline \multirow[t]{5}{*}{ Africa } & Niger & 4 & 38 & 58 & 48 & 1.27 \\
\hline & Nile & 4 & 424 & 11 & 427 & 1.01 \\
\hline & Senegal & 1 & 12 & 3 & 13 & 1.08 \\
\hline & Volta & 1 & 168 & 37 & 173 & 1.03 \\
\hline & Zambezi & 3 & 288 & 59 & 293 & 1.02 \\
\hline \multirow[t]{16}{*}{ Eurasia } & Amu Darya & 5 & 61 & 23 & 72 & 1.18 \\
\hline & Amur & 3 & 94 & 7 & 96 & 1.02 \\
\hline & Brahmaputra & 5 & 71 & 81 & 92 & 1.30 \\
\hline & Chao Phraya & 4 & 32 & 9 & 35 & 1.08 \\
\hline & Dnieper & 4 & 44 & 6 & 49 & 1.12 \\
\hline & Yellow & 4 & 63 & 49 & 77 & 1.22 \\
\hline & Indus & 5 & 49 & 31 & 55 & 1.14 \\
\hline & Irrawaddy & 1 & 4 & 11 & 7 & 1.85 \\
\hline & Krishna & 5 & 38 & 57 & 57 & 1.49 \\
\hline & Lena & 1 & 40 & 3 & 41 & 1.01 \\
\hline & Mekong & 1 & 8 & 20 & 21 & 2.78 \\
\hline & $\mathrm{Ob}$ & 2 & 66 & 5 & 72 & 1.09 \\
\hline & Shatt al-Arab & 13 & 246 & 33 & 260 & 1.05 \\
\hline & Volga & 10 & 217 & 17 & 222 & 1.02 \\
\hline & Yangtze & 8 & 123 & 373 & 218 & 1.79 \\
\hline & Yenisei & 7 & 468 & 7 & 468 & 1.00 \\
\hline \multirow[t]{2}{*}{ Australia } & Murray & 3 & 11 & 56 & 26 & 2.22 \\
\hline & Total & 166 & 3877 & 2095 & 4461 & 1.15 \\
\hline
\end{tabular}

simulated reservoir variations were multiplied by a projection factor $P$ :

$$
P=C_{\text {tot }} / C_{\text {sim }},
$$

where $C_{\mathrm{tot}}$ is the total reservoir capacity for each basin and $C_{\text {sim }}$ is the reservoir capacity within that same basin accounted for in the simulations (Table 3).

Over $70 \%$ of the basins have projection factors less than 1.3 , meaning that the simulated capacity represents at least $75 \%$ of the total capacity for these basins. The average projection factor for all the simulated basins is 1.15; the lowest value is 1.0 for the Yenisei River basin, in which all seven major reservoirs were simulated. The Mekong River basin had the highest projection factor of 2.78 (only one large reservoir out of a total of 20 was simulated). For each basin, the monthly reservoir storage time series $\left[S_{r}\right]$ aggregated over all simulated reservoirs were first averaged to obtain the mean seasonal cycle (by month), which was then projected to the entire basin. The seasonal reservoir storage variation range $\Delta_{r}$ for each basin was computed as the difference between the maximum and minimum reservoir storage values over the mean seasonal cycle. Here, square brackets $[\cdot]$ denote a 12-element vector of the (mean) monthly seasonal cycle of the variable:

$$
\Delta_{r}=\max \left[S_{r}\right]-\min \left[S_{r}\right] .
$$

Our results show that three basins (Yenisei, Yangtze, and Volga) had seasonal reservoir storage variations greater than $50 \mathrm{~km}^{3}$ (Fig. 4), which arises because of their relatively large annual runoff and large installed reservoir capacity. The Nelson basin also experienced a high variation in storage $\left(>40 \mathrm{~km}^{3}\right)$ because Lake Winnipeg, a large freshwater lake, is treated as a reservoir in the simulation (there is a hydropower dam at the lake's outlet). The large water surface area $\left(23500 \mathrm{~km}^{2}\right.$, slightly larger than the state of New Jersey) results in large storage variations even for small changes in water level. The Lena basin had the smallest variation, mainly 


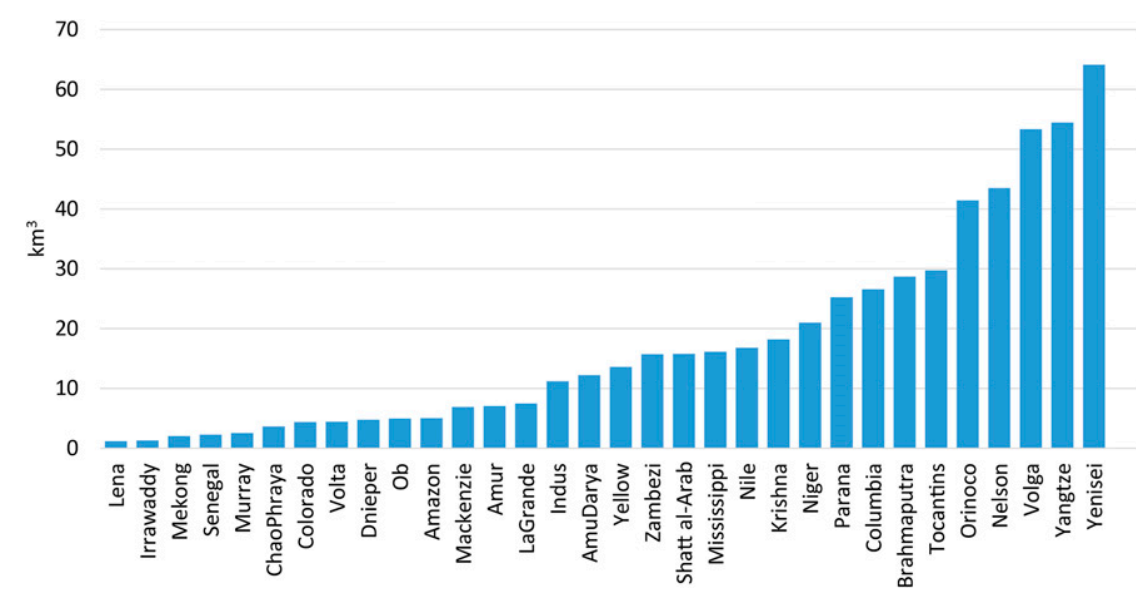

FIG. 4. Seasonal storage variation (expressed as volume) for 32 global basins (ranking from small to large).

because it is a large river basin with modest human regulation. The total seasonal storage variation range for the simulated 32 basins was about $570 \mathrm{~km}^{3}$, or $13 \%$ of the total capacity of these basins.

To quantify the magnitude of the seasonal reservoir storage variations relative to other terms in the surface water budget, we compared the area-projected seasonal reservoir storage (i.e., $\left[S_{r}\right]$ ) with seasonal natural storage including snow $\left[S_{\mathrm{SWE}}\right]$ and soil moisture $\left[S_{\text {soil }}\right]$ for each basin (Fig. S1 in the supplemental material). Here, snow storage is represented by SWE and soil moisture storage by the column-integrated moisture, both represented as a depth $(\mathrm{mm})$. To remove the effects of interannual storage variations (water carried over from year to year), the seasonal cycles for all storage terms were normalized by subtracting the minimum values in each (calendar) year (hence, the minima in the adjusted series was zero for each year).

We first examined storage variations in the 11 basins in which seasonal snow plays an important role. These basins are all located in the Northern Hemisphere and include La Grande, Lena, Mackenzie, Ob, Yenisei, Amu Darya, Amur, Columbia, Indus, Nelson, and Volga, with SWE being the largest contributor to storage variation or with the SWE contribution to storage variation being more than half of the soil moisture contribution (see Fig. $\mathrm{S} 1$ in the supplemental material; Fig. 5a). The seasonal water storage terms were first averaged over the 11 basins and the averaged seasonal reservoir storage was normalized by dividing the seasonal total storage by the drainage area of these basins. Averaged over all 11 basins, the seasonal reservoir storage variation is about $12 \mathrm{~mm}$, which is about $14 \%$ of the averaged SWE variation $(83 \mathrm{~mm})$ and $19 \%$ of the soil moisture variation $(62 \mathrm{~mm})$. Although the phase of the seasonal reservoir storage varies among basins, the peak of the averaged reservoir storage occurred in September, different from the peak soil moisture (May) and SWE (March). We then compared the reservoir storage variation with SWE and soil moisture variations over all 32 global basins
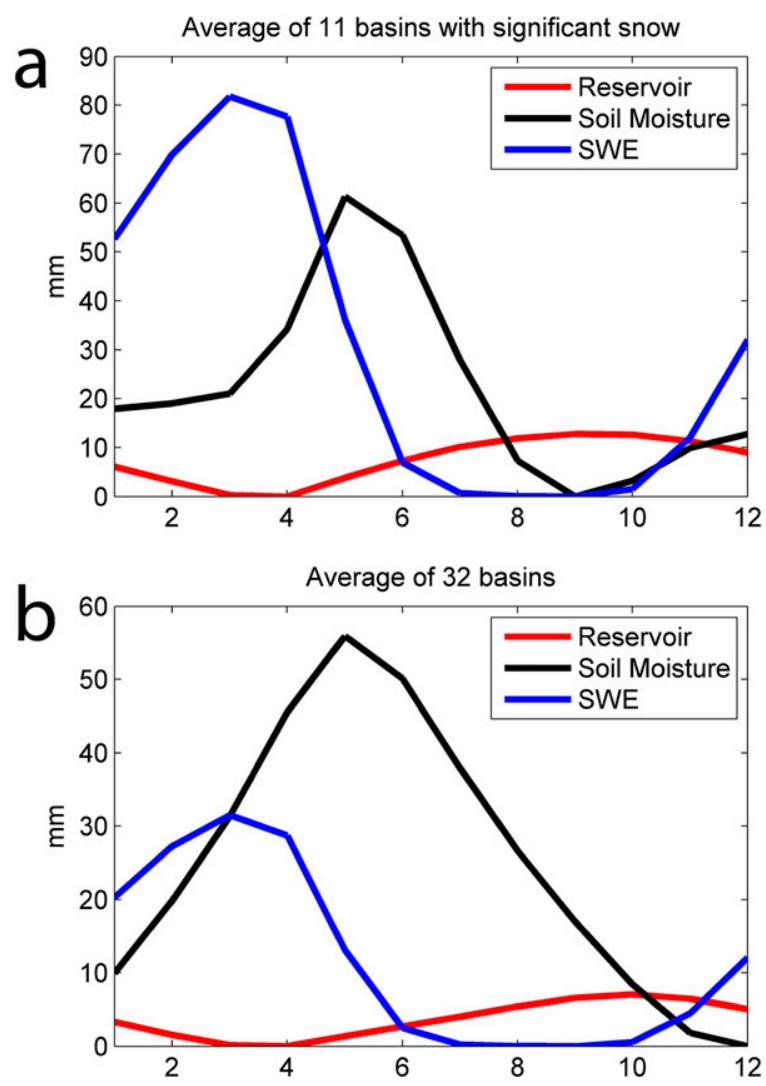

FIG. 5. Values of $\left[S_{r}\right]$ compared with $\left[S_{\mathrm{SWE}}\right]$ and [ $\left.S_{\text {soil }}\right]$ in (a) 11 snow significant basins and (b) all 32 simulated basins. 


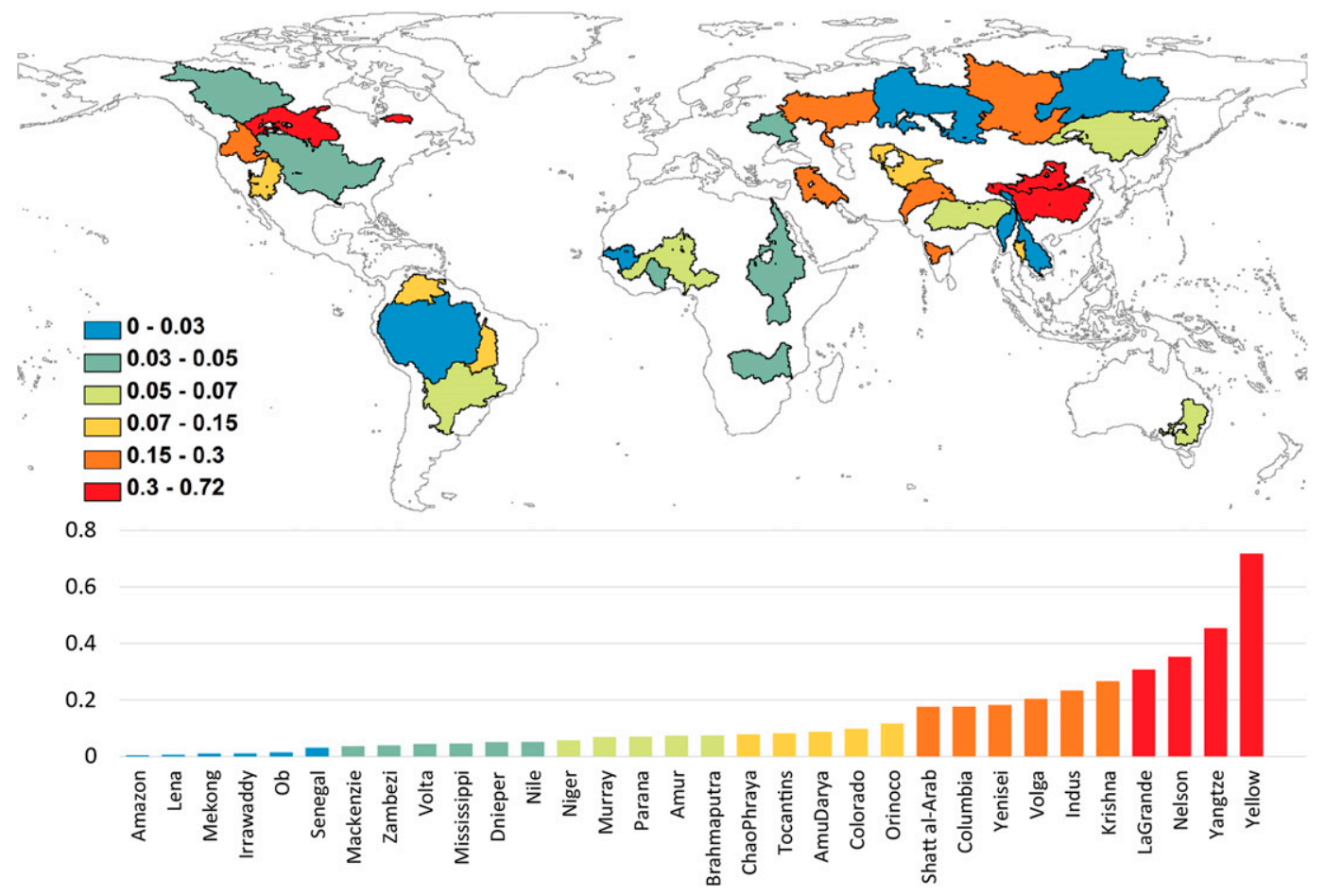

FIG. 6. The seasonal reservoir variation as fraction of natural storage variation for 32 basins.

(Fig. 5b) using the same method. The averaged reservoir storage variation is $7 \mathrm{~mm}$, about $23 \%$ of the SWE variation $(30 \mathrm{~mm})$ and $13 \%$ of the soil moisture variation $(54 \mathrm{~mm})$.

To better compare the storage terms across the basins, we calculated a fraction factor $F$ for each basin to represent reservoir storage variation (i.e., $\Delta_{r}$ ) as a fraction of natural storage variation $\Delta_{n}$ :

$$
F=\Delta_{r} / \Delta_{n},
$$

where

$$
\Delta_{n}=\max \left[S_{n}\right]-\min \left[S_{n}\right]
$$

and

$$
\left[S_{n}\right]=\left[S_{\mathrm{SWE}}\right]+\left[S_{\text {soil }}\right] .
$$

Averaged over all basins, reservoir storage is a modest part of the water cycle ( $\bar{F}=0.1$, not shown in the figure). However, in some intensively dammed basins such as the Yellow River and the Yangtze River, seasonal reservoir storage variations as a fraction of combined SWE and soil moisture can be as large as 0.72 (Fig. 6). Other basins with large $F$ values are the Nelson, Columbia, Volga, and Yenisei, where dams are mostly operated for hydropower generation, and the Krishna and Shatt al-Arab, where dams are operated for both irrigation and hydropower. In contrast, for a number of basins, reservoir storage variations are negligible compared to the natural storage terms. This is the case 1) for relatively large drainage area basins where reservoir storage, expressed as a spatial average, is small (e.g., Mississippi and Nile); 2) when reservoir variations are small because of small installed storage capacity relative to the annual flow (e.g., Mekong); or 3) when both occur (e.g., Amazon and Lena).

We further investigated the dominant source of the variation among these basins. The variation of the three storage terms $\left(\Delta_{r}, \Delta_{\mathrm{SWE}}\right.$, and $\left.\Delta_{\text {soil }}\right)$ were normalized to sum to one and plotted on a ternary diagram (Fig. 7), where

$$
\Delta_{\mathrm{SWE}}=\max \left[S_{\mathrm{SWE}}\right]-\min \left[S_{\mathrm{SWE}}\right]
$$

and

$$
\Delta_{\text {soil }}=\max \left[S_{\text {soil }}\right]-\min \left[S_{\text {soil }}\right]
$$

The diagram has three apexes representing the three storage terms, and the distance from each point to each apex reflects the proportion of this term in the storage cycle. The results reveal that in 27 basins, or $78 \%$ of the simulated area, seasonal storage variation was dominated by soil moisture. In tropical basins such as the Amazon, Mekong, and Irrawaddy, soil moisture 


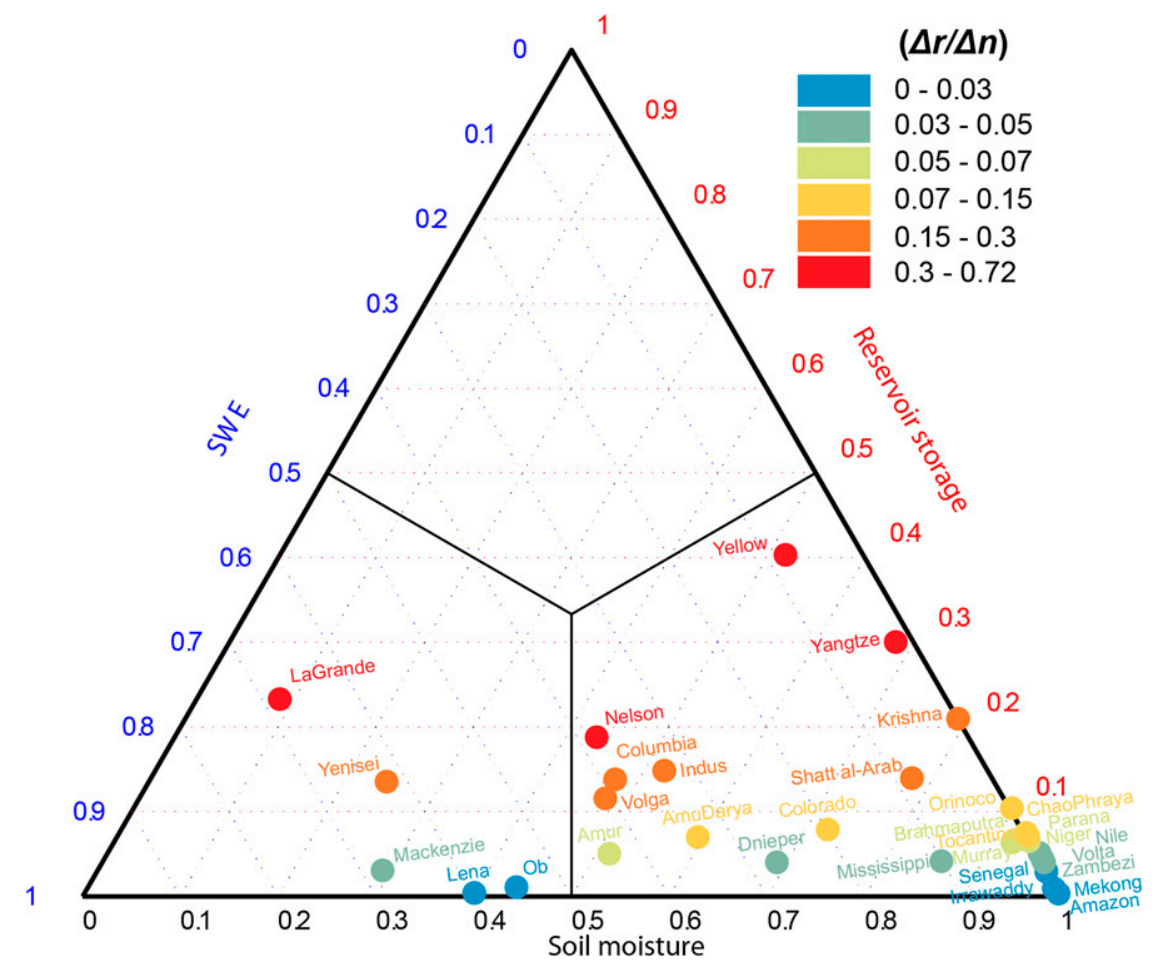

FIG. 7. Ternary plot for the 32 simulated basins. The variation of the storage terms (SWE, soil moisture, and reservoir) for each basin were normalized to the sum of one. Color of each point represents the ratio of reservoir variation and natural variation (i.e., $\Delta_{r} / \Delta_{n}$ ).

accounts for over $95 \%$ of the total storage variation. In five basins (La Grande, Yenisei, Mackenzie, Lena, and $\mathrm{Ob}$ ), or $22 \%$ of the simulated area, SWE was the dominant storage variation term.

Somewhat surprisingly, reservoirs play a minor role in the total storage variation in some highly regulated basins. This is particularly true in basins with low runoff ratios in which streamflow is only a minor component of the hydrological cycle. For example, the Colorado River is so intensively managed that water no longer reaches its mouth for most of the time (Haddeland et al. 2007). Even so, reservoir storage variations are modest relative to the natural terms, because most of the precipitation in the Colorado River basin does not contribute to streamflow but instead returns to the atmosphere as evapotranspiration.

To control for this effect, we also examined relative reservoir storage variations normalized by the annual total runoff for each basin. This measure highlights basins with relatively small runoff and large reservoir storage variations. Expressed this way (see Fig. S2 in the supplemental material), the largest values (for the Nelson, Colorado, Krishna, and Volga) are on the order of 0.15 . The basins with small fractions are mostly concentrated in South America and Africa.

\section{c. Storage term variations at continental scale}

Given that the simulated reservoirs represent nearly $60 \%$ of the global reservoir capacity, we used the projection method from Eq. (1) to estimate total continental and global reservoir storage variations. The projection factors for each continent are given in Table 4. In South America and Africa, the factors are less than 1.67, indicating that the simulated capacity represents over $60 \%$ of the total capacity. In Australia, because of the relatively small reservoir size and the lack of large river basins, we only simulated three reservoirs in the Murray River basin, resulting in a projection factor of 10 . However, given the small contribution of reservoirs in Australia to the global reservoir capacity $(\sim 1.6 \%)$, the impact of the Australian reservoirs is limited. The global average projection factor is 1.79 (i.e., $56 \%$ of the total reservoir storage was simulated).

Globally, the variation of reservoir-related seasonal storage is about $700 \mathrm{~km}^{3}$ or $10 \%$ of global total reservoir capacity. We compared the inferred seasonal reservoir storage with the VIC-simulated seasonal SWE and soil moisture for the Northern Hemisphere and the Southern Hemisphere separately because of the reversed seasonality (Fig. 8). In the Northern Hemisphere (excluding Greenland), the reservoir storage variation is about 
TABLE 4. Summary of simulated and projected reservoirs in five major continents.

\begin{tabular}{|c|c|c|c|c|c|}
\hline Continent & $\begin{array}{l}\text { No. of simulated } \\
\text { reservoirs }\end{array}$ & $\begin{array}{c}\text { Capacity } \\
\text { simulated }\left(\mathrm{km}^{3}\right)\end{array}$ & $\begin{array}{l}\text { Total reservoir number } \\
\text { in continent }\end{array}$ & $\begin{array}{c}\text { Total } \\
\text { capacity }\left(\mathrm{km}^{3}\right)\end{array}$ & $\begin{array}{l}\text { Projection } \\
\text { factor }\end{array}$ \\
\hline North America & 38 & 667 & 2249 & 1918 & 2.94 \\
\hline South America & 34 & 630 & 304 & 963 & 1.56 \\
\hline Africa & 13 & 930 & 750 & 1110 & 1.22 \\
\hline Eurasia & 78 & 1624 & 3304 & 2802 & 1.75 \\
\hline Australia & 3 & 11 & 255 & 107 & 10.00 \\
\hline Total & 166 & 3862 & 6862 & 6900 & 1.79 \\
\hline
\end{tabular}

$6.3 \mathrm{~mm}$, equal to $40 \%$ of the soil moisture and $17 \%$ of the SWE variation. In the Southern Hemisphere (excluding Antarctica), the reservoir storage variation is $3.5 \mathrm{~mm}$, equal to about $2.5 \%$ of the soil moisture variation. Note that most of the Southern Hemisphere has little snow and our areally averaged, simulated SWE variation is only $0.03 \mathrm{~mm}$.

From a continental perspective, the largest seasonal storage variations in South America, Africa, and Australia are from soil moisture, with the largest seasonal variation in South America $(140 \mathrm{~mm})$. SWE variations for these continents are negligible. Reservoir variations are also very low $(<3 \mathrm{~mm})$ because reservoir capacity is small compared to the mean annual flow in most large basins in these continents. North America and Eurasia have similar patterns for the three storage components.
In both continents, the largest storage variation is from seasonal snow $(60 \mathrm{~mm}$ in North America and $45 \mathrm{~mm}$ in Eurasia). Soil moisture is the second largest contributor to storage variations over both continents $(40 \mathrm{~mm}$ in North America and $12 \mathrm{~mm}$ in Eurasia). A cross-continent comparison of reservoir storage variations suggests that the highest variations are for North America (about $10 \mathrm{~mm}$ ), followed by Eurasia $(7 \mathrm{~mm})$, South America $(2 \mathrm{~mm})$, Australia $(1.5 \mathrm{~mm})$, and Africa $(1.2 \mathrm{~mm})$ (see Fig. S3 in the supplemental material).

We also examined the time series of global reservoir storage over the period 1948-2010. The value was calculated by adding the monthly storage time series from each modeled reservoir and then projected to the global land area using the same projection factor (1.79) as in the seasonal variation analysis. Although this value
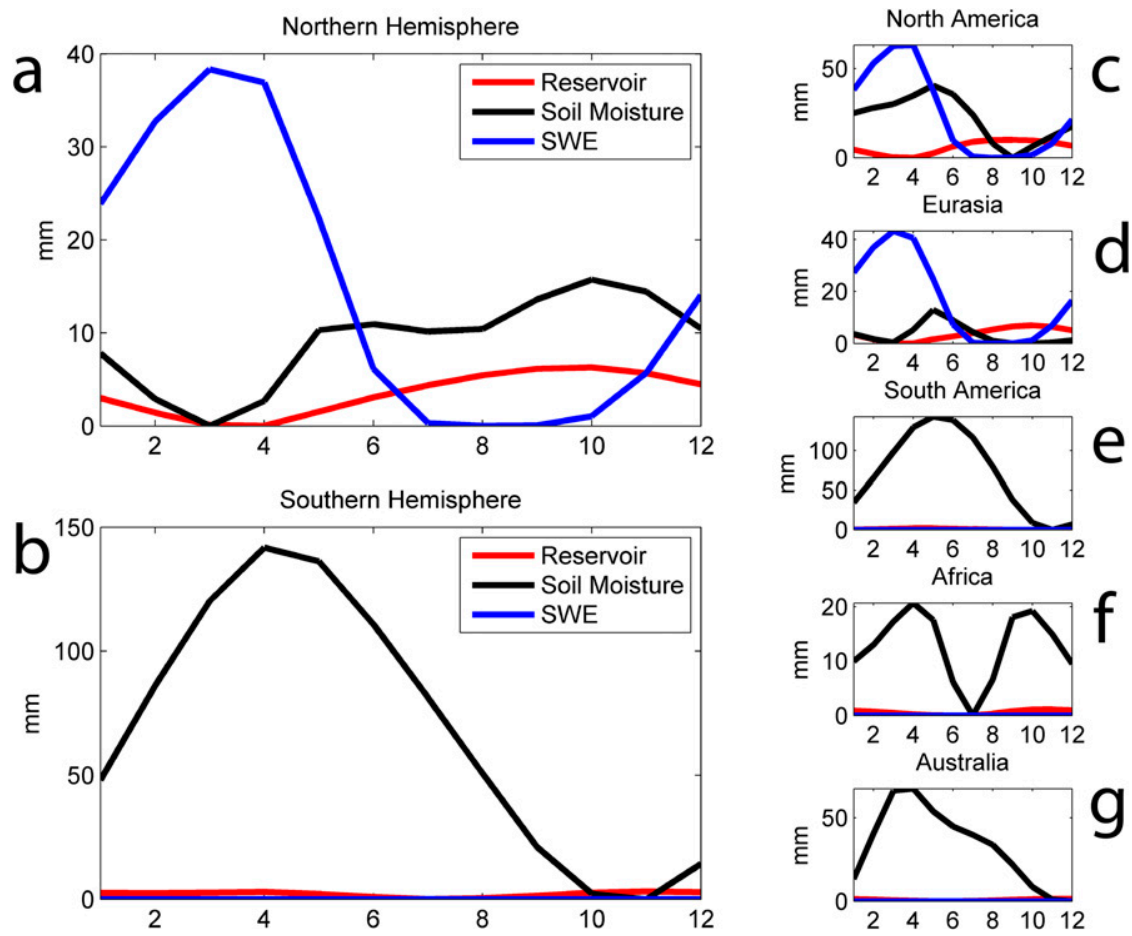

FIG. 8. The seasonal reservoir storage compared with seasonal SWE and soil moisture in

(a) Northern and (b) Southern Hemisphere and (c)-(g) five continents. 


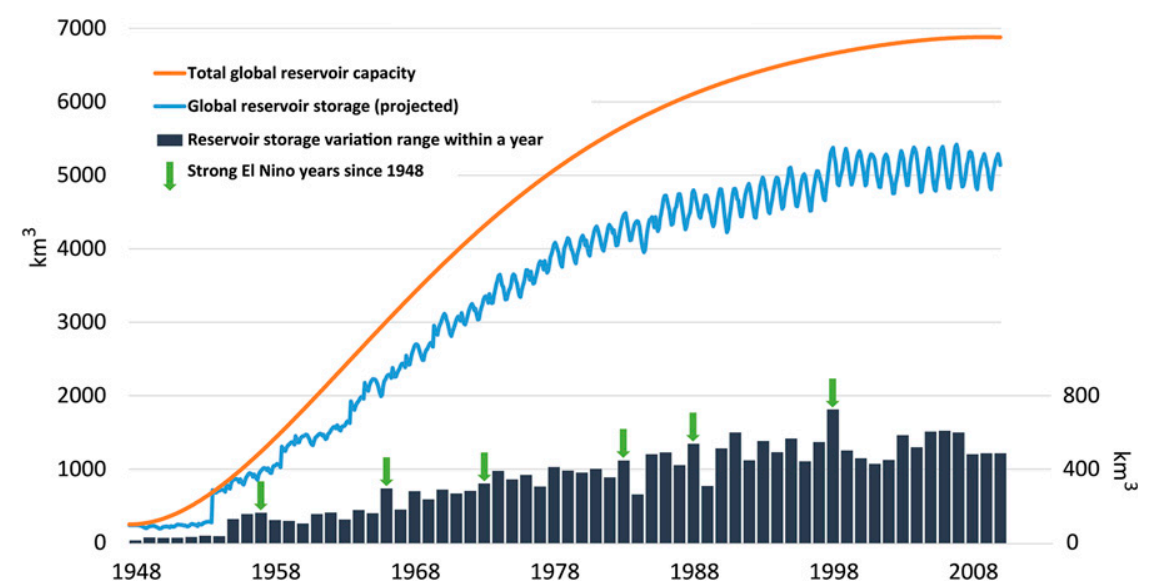

FIG. 9. Time series of global reservoir storage and built capacity from 1948 to 2010. Bar graph shows the global reservoir storage variation range within each year. Strong El Niño years are marked along the time line.

changes over time because of the construction of new dams (and changes in existing ones, e.g., sedimentation), it does provide a rough idea of global storage variations.

The global reservoir storage change reflects the massive expansion of global reservoir capacity over the past half century (Fig. 9). From 1948 to 2010, along with the rapid increase of global total reservoir capacity, the global reservoir active storage grew from about 200 to over $5000 \mathrm{~km}^{3}$, which is over $70 \%$ of the total global capacity $\left(7000 \mathrm{~km}^{3}\right)$. Based on the model results, two basins (Nile and Yenisei) had storage increments greater than $300 \mathrm{~km}^{3}$ during this period. The yearly storage variation range, which we expressed as the difference between the annual maximum and minimum for each year, increases accordingly from $17 \mathrm{~km}^{3}$ in 1948 to over $500 \mathrm{~km}^{3}$ in 2010 , with a maximum variation range (over $700 \mathrm{~km}^{3}$ ) in 1998 . We also defined a term for mean absolute interannual storage variation $\bar{V}$ to quantify the mean annual global reservoir storage change over the analyzing period:

$$
\bar{V}=\frac{\sum_{i=1}^{n}\left|S_{i}-S_{i-1}\right|}{n},
$$

where $S_{i}$ indicates average storage at year $i$. The result suggests that the $\bar{V}$ over $1948-2010$ is about $89 \mathrm{~km}^{3}$.

\section{Discussion}

We examined global reservoir storage variations at seasonal and interannual scales using a large-scale hydrological model coupled with irrigation and reservoir regulation model. The total volume of the seasonal variation estimated here is nearly $700 \mathrm{~km}^{3}$, or about $10 \%$ of the global total reservoir capacity. Biancamaria et al. (2010) reported that the seasonal variation of global lake and reservoir storage was about $9.8 \%$ of the total capacity of global lakes and reservoirs, which is similar to our estimates. One might think that reservoir storage variations would exceed those of lakes as the objective of reservoir operation is to modulate natural variations in streamflow, but on the other hand, for one of the major operating objectives of the reservoir we studied (hydropower), a typical operating policy is to keep the reservoir as full as possible.

If there is in fact an underestimation of reservoir storage variability, there are (at least) three possible causes. First, global reservoir storage variations were inferred by averaging the seasonal phases from simulated reservoirs, which has the effect of smoothing out the signals where they are out of phase. Second, the reservoir database we used does not include all the global reservoirs-we used the GRanD dataset (Lehner et al. 2011), which includes more than 6800 reservoirs with a total capacity less than $7000 \mathrm{~km}^{3}$. The somewhat more comprehensive global reservoir database of the International Commission on Large Dams (ICOLD 2007) contains more than 30000 reservoirs with total capacity of $8300 \mathrm{~km}^{3}$. Presumably, a larger total capacity means a larger projection factor and thus a larger reservoir storage variation. The reason we did not use the ICOLD data is because they do not include geographic information (i.e., latitude and longitude) for the reservoirs, which made it unsuitable for our modeling effort. Third, the projection approach we used to infer total global variations from the 166 reservoirs that we modeled may lead to biases; in particular, we are effectively estimating the behavior of 


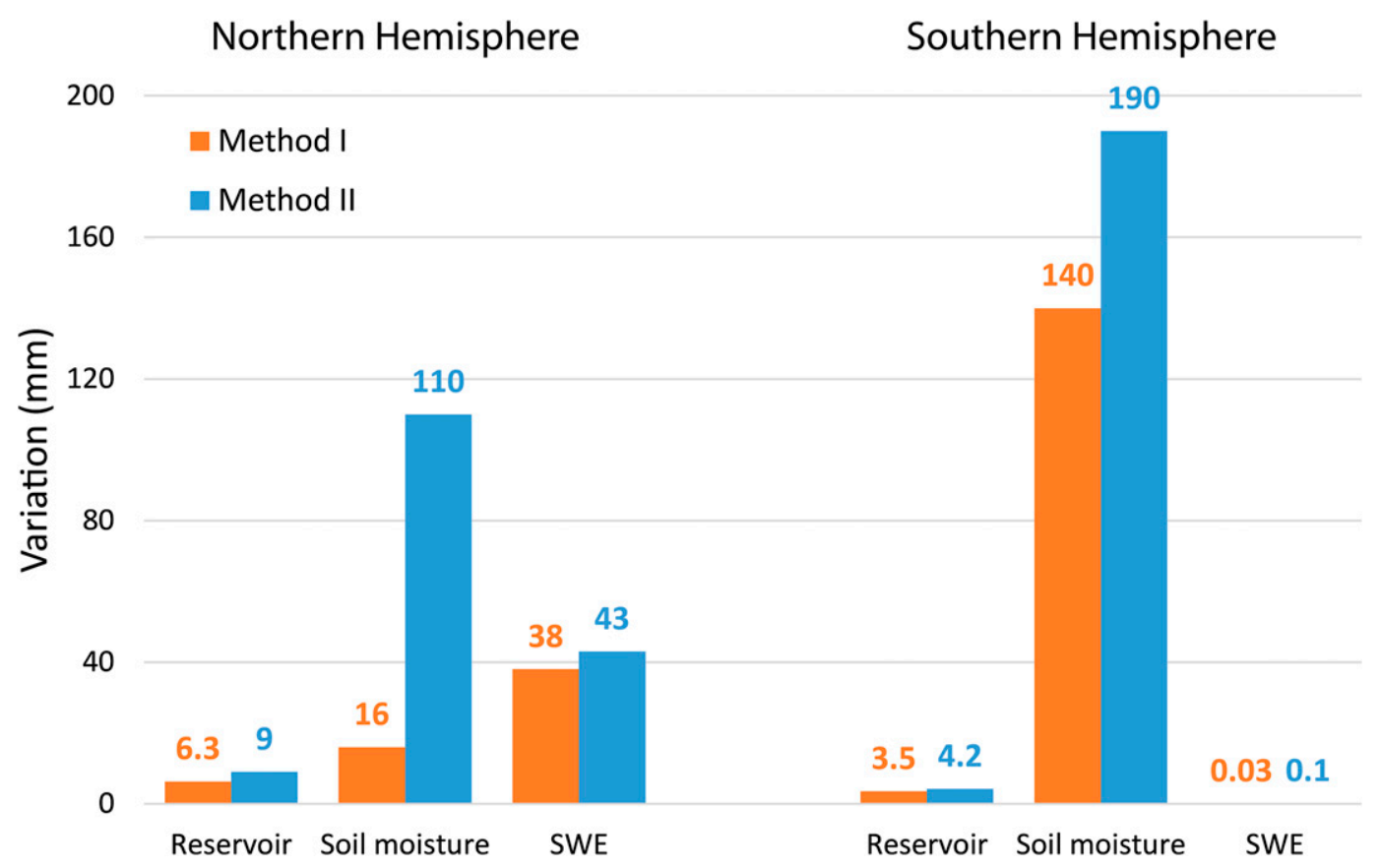

FIG. 10. Variation ranges for reservoir storage, soil moisture, and SWE in the Northern and Southern Hemispheres calculated by two different methods.

smaller reservoirs from the set of larger ones, which may lead to errors.

We believe that of the three issues noted above, the seasonal phase cancelation of storage terms potentially has the largest effect on the storage variation estimates. Therefore, we used a second method to characterize the storage variation range by removing the timing component. In this method (method II), we calculate the variation ranges (i.e., $\Delta_{r}$ ) for storage terms as

$$
\Delta_{r}=\frac{\sum_{i=1}^{n}\left(\max \left[S_{r}\right]-\min \left[S_{r}\right]\right)}{n},
$$

where $n$ is the number of simulated reservoirs (or number of grid cells when calculating SWE and soil moisture) and $\left[S_{r}\right]$ is the mean seasonal storage cycle for a single reservoir (or single grid cell for SWE and soil moisture). Compared to the previous method (method I), method II eliminates the timing component because it averages the range of the storage values from the individual reservoirs (or grid cells), rather than determining the range from the monthly averaged values (method I).

We recalculated the storage variation ranges for the Northern and Southern Hemispheres using method II (Fig. 10). The results suggest that, compared to method I, method II does increase the range of variation of all storage terms, but especially soil moisture in the Northern Hemisphere, whose range increases from 16 to $110 \mathrm{~mm}(>500 \%)$ and becomes the largest term. SWE only increases $5 \mathrm{~mm}(13 \%)$ in the Northern Hemisphere because the timing of the snow accumulation and melt generally follows the same pattern over most river basins. Reservoir storage variation ranges increase from 6.3 to $9 \mathrm{~mm}(43 \%)$ in the Northern Hemisphere and from 3.5 to $4.2 \mathrm{~mm} \mathrm{(20 \% )} \mathrm{in} \mathrm{the} \mathrm{Southern} \mathrm{Hemisphere,} \mathrm{but} \mathrm{because}$ of the much larger increase in the soil moisture variation range, the relative contribution of reservoir storage decreases. In this study, conclusions were generated based on results from method I.

The increasing capacity of reservoirs over the past half century explains the increase in the storage variation range within each year. However, in examining the time series of inferred global reservoir storage variations, we find that the variations may also be associated with global-scale oscillations such as El Niño. In Fig. 9 the strong El Niño years during the past 63 years are marked; five for the six years with the largest (relative) variation ranges are associated with El Niño years, including 1998, which coincide with a strong "lift" in the global reservoir storage time series. This finding may imply some interactions between the climate-changeinduced extreme events and human responses, but the underlining mechanisms remain unclear. 
The water management model we used makes relatively simple assumptions to predict irrigation demand and in specifying reservoir operating rules. Among the improvements that might be considered are groundwater withdrawals, interbasin water transfers, and multiple reservoir operations:

1) Groundwater accounts for about $30 \%$ of global water withdrawals (Gornitz 2000), but groundwater withdrawals are not considered by our model. The implications are somewhat complicated: we assume that irrigation water for areas downstream of the simulated reservoirs is supplied entirely by the reservoir, whereas in fact some of those demands are likely supplied by groundwater. On the other hand, interbasin water transfers mean that irrigation demands outside the basin may be satisfied by the reservoir, but these transfers are not considered (see below), resulting in some cancellation.

2) In a number of cases, reservoirs supply demands outside the basin in which they are located. Among the best-known examples are the Colorado River Aqueduct and the All-American Canal projects, which convey water from the Colorado basin to California (about $8-9 \mathrm{~km}^{3} \mathrm{yr}^{-1}$ ). Our current model does not represent these transfers.

3) In our model, multiple reservoirs in a basin are treated separately, meaning that operation of the downstream reservoir(s) does not take into account the operations of the upstream ones. In fact, where multiple reservoirs are present, their operations are almost always linked. A more sophisticated algorithm that accounts for multiple reservoir operation would be desirable.

This study might be extended in a number of directions. The first would be to identify and capture surface water storage (in river channels and floodplains). In most extratropical river basins, this likely is small in seasonal amplitude (compared with soil moisture and SWE). For example, Lettenmaier and Famiglietti (2006) took the difference between model routed flow at the outlet and accumulated runoff entering the channel for Mississippi River basin and suggested that the seasonal storage variation in the river is negligible compared to soil moisture variations. However, for some tropical rivers (e.g., the Amazon), studies have shown that the seasonal amplitude of river and floodplain storage can be substantial (for instance, $1000-1200 \mathrm{~km}^{3}$ or about $200 \mathrm{~mm}$ averaged over the basin area; Getirana et al. 2012; Frappart et al. 2012; Papa et al. 2013). In VIC, the dynamics of river channel and floodplain storage are not estimated explicitly; however, it is likely that some of the soil moisture storage variations act as a surrogate for river and floodplain storage. Therefore, it is not correct simply to add estimates like those above to our inferred soil moisture variation amplitude (which likely is too high). These inferences do point to the need to incorporate more physically realistic river and floodplain storage algorithms into land surface models.

The second pathway would be to focus on increasing the number of reservoirs and to simulate more basins. According to the GRanD database, a total of 728 reservoirs globally have capacity greater than $1 \mathrm{~km}^{3}$, which represents $>70 \%$ of the global capacity. Representing these reservoirs explicitly within the current model structure appears feasible (to represent many more probably would require aggregation in some way), although our simulations of smaller reservoirs were not as good as for larger ones when compared with satellitebased reservoir storage estimates.

The third pathway would focus more on reservoir operating rules and attempt to better represent those rules for the reservoirs that are simulated. Most reservoir operating agencies have models that are used for planning purposes and that encode their operating policies. Although these models are highly site specific, additional evaluation of reservoir storage observations, along with some site-specific analysis, may allow improvements to the generic operating rules that we incorporate in our model.

\section{Conclusions}

We simulated monthly reservoir storage time series for 166 large global reservoirs, which represent nearly $60 \%$ of global total reservoir capacity. Based on those results, we extrapolated to the continental and global level. We find the following:

1) The total volume associated with seasonal variations in reservoir storage globally is nearly $700 \mathrm{~km}^{3}$, or $10 \%$ of the global total reservoir capacity.

2) Reservoir seasonal storage variations are about $6.3 \mathrm{~mm}$ averaged over the Northern Hemisphere (excluding Greenland). This is about $40 \%$ of the magnitude of the seasonal variation in soil moisture and $17 \%$ of the SWE variation. For the Southern Hemisphere (excluding Antarctica), the reservoir storage variations are $3.5 \mathrm{~mm}$, about $2.5 \%$ of the soil moisture variation.

3) The basins with relatively large seasonal reservoir storage variations are concentrated in North America and Eurasia. In some intensively dammed basins, the seasonal reservoir variation as a fraction of combined SWE and soil moisture can be as high as 0.72 . 
4) Global reservoir storage increased rapidly over the past 60 years, more or less in concert with the rate of reservoir storage construction. The mean absolute interannual storage variation during $1948-2010$ is $89 \mathrm{~km}^{3}$.

5) Peak yearly variation range in global reservoir storage may be associated with global-scale extreme events such as El Niño, but the underlying causes need further investigation.

Acknowledgments. This research was supported by NASA Making Earth System Data Records for Use in Research Environments (MEaSUREs) program (NNX08AN40A) and NASA Energy and Water Cycle Study (NEWS) program (NNX13AD26G) to the University of Washington. The authors thank Dr. Ingjerd Haddeland of Norwegian Water Resources and Energy Directorate and Dr. Justin Sheffield of Princeton University for data and programming assistance.

\section{REFERENCES}

Biancamaria, S., and Coauthors, 2010: Preliminary characterization of SWOT hydrology error budget and global capabilities. IEEE J. Sel. Top. Appl. Earth Obs. Remote Sens., 3, 6-19, doi:10.1109/JSTARS.2009.2034614.

Biemans, H., I. Haddeland, P. Kabat, F. Ludwig, R. Hutjes, J. Heinke, W. Von Bloh, and D. Gerten, 2011: Impact of reservoirs on river discharge and irrigation water supply during the 20th century. Water Resour. Res., 47, W03509, doi:10.1029/2009WR008929.

Chao, B. F., Y. H. Wu, and Y. S. Li, 2008: Impact of artificial reservoir water impoundment on global sea level. Science, 320, 212-214, doi:10.1126/science.1154580.

Christensen, N. S., A. W. Wood, N. Voisin, D. P. Lettenmaier, and R. N. Palmer, 2004: The effects of climate change on the hydrology and water resources of the Colorado River basin. Climatic Change, 62, 337-363, doi:10.1023/B:CLIM.0000013684.13621.1f.

Coughlan, M., and R. Avissar, 1996: The Global Energy and Water Cycle Experiment (GEWEX) Continental-Scale International Project (GCIP): An overview. J. Geophys. Res., 101, 7139-7147, doi:10.1029/96JD00125.

Dirmeyer, P. A., 1995: Problems in initializing soil wetness. Bull. Amer. Meteor. Soc., 76, 2234-2240.

Döll, P., K. Fiedler, and J. Zhang, 2009: Global-scale analysis of river flow alterations due to water withdrawals and reservoirs. Hydrol. Earth Syst. Sci., 13, 2413-2432, doi:10.5194/ hess-13-2413-2009.

Duan, Q., S. Sorooshian, and V. K. Gupta, 1994: Optimal use of the SCE-UA global optimization method for calibrating watershed models. J. Hydrol., 158, 265-284, doi:10.1016/ 0022-1694(94)90057-4.

Fekete, B. M., C. J. Vörösmarty, and W. Grabs, 2002: Highresolution fields of global runoff combining observed river discharge and simulated water balances. Global Biogeochem. Cycles, 16, 15-1-15-10, doi:10.1029/1999GB001254.

Frappart, F., F. Papa, J. Santos da Silva, G. Ramillien, C. Prigent, F. Seyler, and S. Calmant, 2012: Surface freshwater storage and dynamics in the Amazon basin during the
2005 exceptional drought. Environ. Res. Lett., 7, 044010 , doi:10.1088/1748-9326/7/4/044010.

Gao, H., C. Birkett, and D. P. Lettenmaier, 2012: Global monitoring of large reservoir storage from satellite remote sensing. Water Resour. Res., 48, W09504, doi:10.1029/ 2012WR012063.

Getirana, A., A. Boone, D. Yamazaki, B. Decharme, F. Papa, and N. Mognard, 2012: The Hydrological Modeling and Analysis Platform (HyMAP): Evaluation in the Amazon basin. J. Hydrometeor., 13, 1641-1665, doi:10.1175/JHM-D-12-021.1.

Gordon, L. J., W. Steffen, B. F. Jonsson, C. Folke, M. Falkenmark, and A. Johannessen, 2005: Human modification of global water vapor flows from the land surface. Proc. Natl. Acad. Sci. USA, 102, 7612-7617, doi:10.1073/pnas.0500208102.

Gornitz, V., 2000: Impoundment, groundwater mining, and other hydrologic transformations: Impacts on global sea level rise. Sea Level Rise: History and Consequences, B. C. Douglas, M. S. Kearney, and S. P. Leatherman, Eds., Academic Press, 97-119.

Haddeland, I., T. Skaugen, and D. P. Lettenmaier, 2006: Anthropogenic impacts on continental surface water fluxes. Geophys. Res. Lett., 33, L08406, doi:10.1029/2006GL026047.

,$- \ldots$, and — 2007: Hydrologic effects of land and water management in North America and Asia: 1700-1992. Hydrol. Earth Syst. Sci., 11, 1035-1045, doi:10.5194/hess-11-1035-2007.

Hanasaki, N., S. Kanae, and T. Oki, 2006: A reservoir operation scheme for global river routing models. J. Hydrol., 327, 22-41, doi:10.1016/j.jhydrol.2005.11.011.

ICOLD, 2007: World Register of Dams 2007. International Commission on Large Dams, accessed 10 October 2013. [Available online at http://www.icold-cigb.org/GB/World_register/world_ register.asp.]

Kinter, J., and J. Shukla, 1990: The global hydrologic and energy cycles: Suggestions for studies in the pre-Global Energy and Water Cycle Experiment (GEWEX) period. Bull. Amer. Meteor. Soc., 71, 181-189, doi:10.1175/1520-0477(1990)071<0181: TGHAEC $>2.0 . \mathrm{CO} ; 2$.

Lehner, B., and Coauthors, 2011: High-resolution mapping of the world's reservoirs and dams for sustainable river-flow management. Front. Ecol. Environ., 9, 494-502, doi:10.1890/ 100125 .

Lettenmaier, D. P., and J. S. Famiglietti, 2006: Hydrology: Water from on high. Nature, 444, 562-563, doi:10.1038/444562a.

_ and P. Milly, 2009: Land waters and sea level. Nat. Geosci., 2, 452-454, doi:10.1038/ngeo567.

Liang, X., D. P. Lettenmaier, E. F. Wood, and S. J. Burges, 1994: A simple hydrologically based model of land surface water and energy fluxes for general circulation models. J. Geophys. Res. 99, 14 415-14 428, doi:10.1029/94JD00483.

Lohmann, D., R. Nolte-Holube, and E. Raschke, 1996: A largescale horizontal routing model to be coupled to land surface parametrization schemes. Tellus, 48A, 708-721, doi:10.1034/ j.1600-0870.1996.t01-3-00009.x.

_ E. Raschke, B. Nijssen, and D. Lettenmaier, 1998: Regional scale hydrology: I. Formulation of the VIC-2L model coupled to a routing model. Hydrol. Sci. J., 43, 131-141, doi:10.1080/ 02626669809492107.

Nijssen, B., G. M. O'Donnell, D. P. Lettenmaier, D. Lohmann, and E. F. Wood, 2001a: Predicting the discharge of global rivers. J. Climate, 14, 3307-3323, doi:10.1175/1520-0442(2001)014<3307: PTDOGR $>2.0 . \mathrm{CO} ; 2$.

, R. Schnur, and D. P. Lettenmaier, 2001b: Global retrospective estimation of soil moisture using the variable infiltration 
capacity land surface model, 1980-93. J. Climate, 14, 1790-1808, doi:10.1175/1520-0442(2001)014<1790:GREOSM>2.0.CO;2.

Oki, T., and S. Kanae, 2006: Global hydrological cycles and world water resources. Science, 313, 1068-1072, doi:10.1126/science.1128845.

Papa, F., F. Frappart, A. Güntner, C. Prigent, F. Aires, A. C. V. Getirana, and R. Maurer, 2013: Surface freshwater storage and variability in the Amazon basin from multi-satellite observations, 1993-2007. J. Geophys. Res. Atmos., 118, $11951-$ 11965, doi:10.1002/2013JD020500.

Pokhrel, Y. N., N. Hanasaki, P. J. Yeh, T. J. Yamada, S. Kanae, and T. Oki, 2012: Model estimates of sea-level change due to anthropogenic impacts on terrestrial water storage. Nat. Geosci., 5, 389-392, doi:10.1038/ngeo1476.

Sheffield, J., G. Goteti, and E. F. Wood, 2006: Development of a 50-year high-resolution global dataset of meteorological forcings for land surface modeling. J. Climate, 19, 3088-3111, doi:10.1175/JCLI3790.1.

Siebert, S., V. Henrich, K. Frenken, and J. Burke, 2013: Global Map of Irrigation Areas version 5. Rheinische FriedrichWilhelms-University/Food and Agriculture Organization of the United Nations, accessed 5 January 2014. [Available online at http:/www.fao.org/nr/water/aquastat/irrigationmap/index10.stm.]

Thenkabail, P. S., and Coauthors, 2009: Global irrigated area map (GIAM), derived from remote sensing, for the end of the last millennium. Int. J. Remote Sens., 30, 3679-3733, doi:10.1080/ 01431160802698919.

Tranvik, L. J., and Coauthors, 2009: Lakes and reservoirs as regulators of carbon cycling and climate. Limnol. Oceanogr., 54, 2298-2314, doi:10.4319/lo.2009.54.6_part_2.2298.
USGS, 2014: One estimate of global water distribution. The World's Water, U.S. Geological Survey, accessed 4 June 2014. [Available online at http://water.usgs.gov/edu/earthwherewater. html.]

Vörösmarty, C. J., K. P. Sharma, B. M. Fekete, A. H. Copeland, J. Holden, J. Marble, and J. A. Lough, 1997: The storage and aging of continental runoff in large reservoir systems of the world. Ambio, 26 (4), 210-219.

- M. Meybeck, B. Fekete, K. Sharma, P. Green, and J. Syvitksi, 2003: Anthropogenic sediment retention: Major global impact from registered river impoundments. Global Planet. Change, 39, 169-190, doi:10.1016/S0921-8181(03)00023-7.

Vrugt, J. A., H. V. Gupta, W. Bouten, and S. Sorooshian, 2003: A Shuffled Complex Evolution Metropolis algorithm for optimization and uncertainty assessment of hydrologic model parameters. Water Resour. Res., 39, 1201, doi:10.1029/ 2002WR001642.

Wang, H., Z. Yang, Y. Saito, J. P. Liu, and X. Sun, 2006: Interannual and seasonal variation of the Huanghe (Yellow River) water discharge over the past 50 years: Connections to impacts from ENSO events and dams. Global Planet. Change, 50, 212-225, doi:10.1016/j.gloplacha.2006.01.005.

White, W. R., 2005: World water storage in man-made reservoirs. Rep. FR/R0012, Foundation for Water Research, Marlow, United Kingdom, 40 pp.

Wu, H., J. S. Kimball, N. Mantua, and J. Stanford, 2011: Automated upscaling of river networks for macroscale hydrological modeling. Water Resour. Res., 47, W03517, doi:10.1029/ 2009WR008871. 